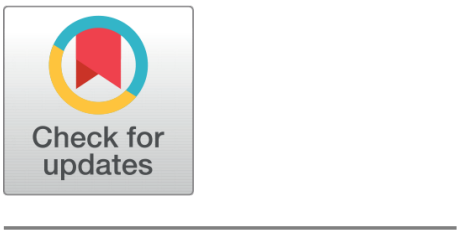

G OPEN ACCESS

Received: 15-04-2020

Accepted: 24-04-2020

Published: 16-05-2020

Editor: Dr. Natarajan Gajendran

Citation: Tupas FP (2020) Up close and personal: An expedition to the last frontier of Sara, Western Philippines. Indian Journal of Science and Technology 13(13): 1380-1389. https ://doi.org/10.17485/IJST/v13i13.44

* Corresponding author.

Fernan Peniero Tupas

Northern Iloilo Polytechnic State College, Estancia, Iloilo, Philippines

International Research Fellow, Japan Society for Promotion Science (JSPS),

Tokyo, Japan

Hokkaido University of Education, Hakodate, Hokkaido, Japan

fernantupas@yahoo.com

Funding: None

Competing Interests: The author declared no competing interest

Copyright: (c) 2020 Tupas. This is an open access article distributed under the terms of the Creative Commons Attribution License, which permits unrestricted use, distribution, and reproduction in any medium, provided the original author and source are credited.

Published By Indian Society for Education and Environment (iSee)

\section{Up close and personal: An expedition to the last frontier of Sara, Western Philippines}

\author{
Fernan Peniero Tupas ${ }^{1,2,3 *}$ \\ 1 Northern Iloilo Polytechnic State College, Estancia, Iloilo, Philippines \\ 2 International Research Fellow, Japan Society for Promotion Science (JSPS), Tokyo, Japan \\ 3 Hokkaido University of Education, Hakodate, Hokkaido, Japan
}

\section{Abstract}

Purpose: This study aims to document flora and fauna found in Sampunong Bolo Wild Sanctuary at the Municipality of Sara, Iloilo, Philippines. The results provide basis for further study, as well as, creating policy and ordinances to protect and preserve the sanctuary. Methods: This study used narrative inquiry. The different methods employed are photo-elicitation, ethnographic research, automated micro-targeting, interview, and document analysis. The informants were purposively selected from Municipal Environment and Natural Resources Office of Municipality of Sara, personnel from Community Environment and Natural Resources Office located at San Dionisio, Iloilo, and Department of Environment and Natural Resources, Regional Office Vl, former forest rangers, barangay officials and local environmentalists. Findings/application: The responses revealed that indeed the place has a highly diverse forest ecosystem but not documented. Two migrating types of birds found roosting in the habitat but because of human intervention such as hunting and gun shooting to disturb the herons. These migrating birds feed on fishes from neighboring fishponds. The abundance of fruit bats leads to the increase prevalence of fruit-bearing trees because of seed dispersal by them. Also, colorful butterflies, local birds, snakes, and camouflage geckos were observed. Furthermore, there were 13 major species of plants in the sanctuary but human activities like 'kaingin,' as well as for the construction of houses caused deforestation. Besides, the sanctuary is the source of portable water in the municipality. The local government together with the national government should find ways to help protect the sanctuary by creating policies and ordinances. Politically, the interest among local officials must be enhanced, and education campaigns about the importance of local biodiversity must be organized.

Keywords: Local biodiversity; Flora and Fauna; Local Government Unit; Sampunong Bolo 


\section{Introduction}

The Philippines is one of the megadiverse countries in the world ${ }^{(1)}$. Home to almost $70-80 \%$ flora and fauna found in this archipelago. The ideal location of the Philippines as a tropical climate acts as a habitat for around 2000 plant species ${ }^{(2)}$. There were many research studies done and these unveiled impressive findings of the richness of the country in terms of biodiversity. For instance, Mt. Makiling in Laguna has more tress compared to United States. But today, the Philippines ranks among the most threatened regions in terms of flora and fauna. There are almost $25 \%$ of vertebrates, $68 \%$ of invertebrates and $84 \%$ of plants highly endangered nowadays in the entire archipelago ${ }^{(3)}$. Endemic species are the most affected organisms and many undiscovered species were already extinct before science unveiled them ${ }^{(1)}$. The implementation of rules to protect the environment and its ecosystems are very poor in the Philippines. Department of Environment and Natural Resources together with Local Government Units (LGU) faced difficulties in the implementation of laws and policies due to lack of enforcement and insufficient funding ${ }^{(4)}$. Human activities, as well as natural disasters, cause so much destruction to these places. The local government together with public and private institutions should work hand in hand to safeguard these natural resources. Today, the national government is very vigilant to protect our resources. Various rehabilitation programs have been organized, and big budgets are allocated.

The northern part of Iloilo is famous for the vast scenery of marine and upland ecosystems. These natural resources become the subject of different researches of government agencies. Specifically, Northern Iloilo Polytechnic State (NIPSC) is the lone college in the district that has conducted various studies on the ecosystem. Thus, the local government unit has to maintain the sustainability of the seagrass ecosystem in Islas de Gigantes. The 9.5 hectares of coral reef in three barangays of Sicogon Island found out that coral is the most valuable resource on the island. This ecosystem provides livelihood programs to the residents ${ }^{(5)}$. In Siccogon, there were 318 species of plants, recorded in the study area. These include species of 252 trees out of which 32 are endemic in Panay. About 7 families and 21 species of herpeto fauna were also recorded. Six species of frogs, 1 toad, 4 skinks, 6 geckoes, 1 varanid and 3 species of snakes were also documented ${ }^{(6)}$.

However, these natural habitats due to economic development as well as for survival are being destroyed. Educating the public is the best solution to these perennial issues, by assessing the status and situations of these ecosystems in northern Iloilo is one of the solutions to protect and preserve the local habitat. These ecosystems can be also used in tourism because many people travel to witness these beautiful places. Thus, this must be protected sustainably and will help to provide livelihood programs to the residents.

One of the international agenda for the past decades is to solve the problem on the environment and biodiversity ${ }^{(7)}$. The lives of the people improved rapidly but the environment is in great danger despite that humans relied independently upon biological resources. Urban design and development is a key threat in species diversity. Thus, government agencies should look into the benefit of transparent, efficient and sustainable urban planning ${ }^{(8)}$.

The sanctuary is a managed protected area that consists of different biotic and abiotic factors. A wildlife sanctuary is about protecting various organisms for conservation, it should limit the human activities such as hunting, cutting of trees and clearing the area for agriculture ${ }^{(9)}$. These regulations of the sanctuary should be implemented similarly for both the government and private entities. The wildlife sanctuaries are established to protect the endangered species ${ }^{(10)}$. But to relocate these animals are difficult and require more time and money ${ }^{(11)}$. Inside a sanctuary, endangered species are specially monitored regularly. The government or private sectors have a team of experts to examine the status of these organisms. During the studies the fauna could be provided with condusive conditions to reproduce and grow in number while under protection. Also, the sanctuary has facilities and equipment for injured and abandoned animals that can rehabilitated before releasing them in the forest. Wildlife sanctuaries preserve the endangered species and protect them from danger ${ }^{(12)}$. While according to the Convention on Biological Diversity (1992) protects the areas in the geographic location where various organisms are structured and managed to accomplish the goal of conservation ${ }^{(13)}$.

Thus, these natural resources are of critical importance because it provides food, freshwater, livelihoods and climate resilience to Filipinos. Protecting and preserving these natural habitats is important to be included in both the national agenda and research priorities of agencies concerned, through these the natural reserve will be assessed and intervention will be made. This study is anchored on Biodiversity Theory since the target is to document all the species found in the sanctuary. The concept started with R. A. MacArthur and E. O. Wilson, the biologists in the 60s, a proposal of a theory of island biogeography explaining about the number of different species on a specific island. They revealed that the availability of different organisms is threatened by three major factors, extinction, colonization, and speciation ${ }^{(14)}$.

Biodiversity is the basis of the interconnection between ecosystem services and human well-being. Thus, this is defined as 'the variability among living organisms from all sources including, inter alia, terrestrial, marine and other aquatic ecosystems and the ecological complexes of which they are part of; this includes diversity within species, between species and of ecosystems ${ }^{(15)}$. 
Therefore, Biodiversity Theory is about significant conservation action to assess and evaluate the status of the ecosystem ${ }^{(16)}$.

This study was formulated because of the project 'SAVING SAMPUNONG BOLO WILDLIFE SANCTUARY' in the Municipality of Sara, Western Philippines. Upon seeing lush green trees from the distance and sounds of various flying animals and running water from the entrance, the sanctuary has great potentials in many ways. The lack of interest of the local government unit to document the sanctuary motivated the researcher to make the first move. This is the basis for the future endeavor for the Sampunong Bolo. This is sustainable to protect and preserve the last frontier in northern Iloilo. This is also to let the next generation appreciate fact safegaurding our natural resources is possible even though development embraces local cities, towns, and municipalities.

Thus, this study aims to document the flora and fauna found in Sampunong Bolo Wildlife Sanctuary in the Municipality of Sara, Iloilo, Philippines. Furthermore, the results of the study will be the basis for LGU-Sara, CENRO, and DENR to create a policy to protect and preserve the sanctuary. This is also a call for the education sectors to make a move to use the sanctuary as instructional materials to educate the learners about the importance of our ecosystem.

\section{Methods}

\subsection{Research design}

The narrative approach was used in this study to intertwine the structure of occasions to form a unified story ${ }^{(17)}$ about the Sampunong Bolo Wildlife Sanctuary; however, this study was focused on documenting flora and fauna as the basis for further studies.

\subsection{Methods of research}

This study employed methods such as ethnographic research, automated micro-targeting, photo elicitation, interviews, and document analysis. In Japan, ethnographic research was used such as site visit inside the barangay where the sanctuary is located. The researcher visited the sites many times to document and observe the local species found in the area. Also, for months the activities of the residents as well as visitors in the sanctuary were closely observed. The researcher also looks for experts who have first-hand experienced in the sanctuary. This automated micro-targeting was selected because social media like Facebook that was used as the main tool during the interviews. Furthermore, the researcher commissioned many artists to draw some species found in the area based on the description of the informants. These illustrations were interpreted and this method this is photo-elicitation. Then, one on one interview was organized for some selected informants. All the documents related to Sampunong Bolo were collected. These were taken from the Local Government Unit (LGU) Sara, and Department of Environment and Natural Resources (DENR) Regional and Municipal Offices.

\subsection{Informants}

The informants of this research are purposively selected. These were personnel from Municipal Environment and Natural Resources Office (MENRO) personnel, barangay officials of Juaneza, former forest rangers of the sanctuary of the LGU SARA, Community Environment and Natural Resources Office (CENRO) personnel located at the Municipality of San Dionisio, (DENR) Region VI, and retired environmentalists.

\subsection{Instruments}

A permit was distributed to concerned officials who managed and handled the sanctuary. The instrument utilized in this study was ready-made-questionnaire that was used as a guide during the interview. These open-ended questions allowed the informants to respond independently. A tape recorder was used in the interview to capture all the details of the responses of the informants.

All the questions were translated by Hiligaynon to have a better understanding of the topics. Each informant was given 15-30 minutes during the interview. Some documents found in LGU-Sara, CENRO, and DENR-TVI were also utilized as a tool.

\subsection{Analysis}

The replies from the interviews were transcribed, coded, and segregated based in the themes. The observations and documents were also analyzed. All documents were analyzed vigorously. All the data from observation, interview and documents were triangulated. 


\subsection{Ethical consideration}

All the informants were given a code name. All the data collected were destroyed after the completion of the study.

\section{Results}

\subsection{The origin of Sampunong Bolo}

There were no data available about Sampunong Bolo except for the blueprint or the map kept by MENRO-Sara. This 52 hectares Sampunong Bolo is located in Barangay Juaneza in the Municipality of Sara. The mountainous area shares its common borders with Barangays Castor, Tady, Ardemil, and Aquirre of the Municipality of San Dionisio.

According to Barangay Captain; "The name Sampunong Bolo according to my great grandfather was because of Bolo a type of bamboo present in the area."

Bambusa levis Blanco or its synonyms Gigantochloa levis which is locally called 'Bolo'. It is a very thin bamboo that grows in the midlands. This an evergreen walled, erect, woody clump of about 15-20-meter-tall with 9-13 centimeter, it has an aerial root that is produced from the nodes. Furthermore, the lower portion of the leaf is light green and young but the sheath is yellow-green with stiff hairs almost yellow. This type of bamboo is used for building construction, making modern furniture and shoots are also edible ${ }^{(18)}$.

According to the DENR Regional Office in Iloilo City, they wanted to recommend to the national government to declare the area as protected. An area can be declared as protected if its home for diverse species of plants and animals or the site is diverse and unique. According to the National Integrated Protected Areas System (NIPAS) under Republic Act 7586 in 1992, the protected area is a portion of a certain region whether land and water with exceptional physical and biological importance. They were categorized into 6 areas, one of that is the wildlife sanctuary. The wildlife sanctuary is an area having the natural condition of species or group species as well as a community of distinctive organisms and physical features ${ }^{(19)}$.

\subsection{Migratory birds}

Summarizes the responses of the informants about different migratory birds in the sanctuary. One of the distinguishing fauna of the sanctuary is having migratory birds. These birds wandered during winter seasons from their place of origin to seek shelter and food. The abundance of other resources in northern Iloilo such as rice fields, fishponds, and marine resources encourage herons to migrate to Sampunong Bolo. The vast resources in the sanctuary were also one of the reasons these birds migrate from their home. This timberland consisting of a variety of plant, animal species and a unique characteristic of this sanctuary is the migratory species such as herons. They usually migrate to warmer countries with open waters or ponds because they feed on fishes ${ }^{(20)}$.

The herons such as purple heron (Ardea pupurea Linn) and rufus-night (Nycticorax caledonicus) are dominant migrating birds. Rainfall and food, play an important role in the breeding of these herons, they usually migrate and stay in flocks from October to March at Australia; February to May at the Philippines; and February to June at Java ${ }^{(21)}$. Purple heron or commonly called as the 'imperial heron' and has a vibrant color. The appearance of this heron is regal being very elongated, narrow-bodied and identified as long thin head and bill with long neck. It also has extended toes and kinked, snake-like neck. The neck is coiled into an s-shape when in flight ${ }^{(22)}$. They feed on a very varied diet consisting of fish, salamanders, frogs, insects, crustaceans, spiders, mollusks, small birds, mammals, snakes, and lizards ${ }^{(23)}$. They hunt by hiding in vegetation motionless and waiting until it approaches. Another heron found in the sanctuary was the Rufus night-heron, also known as the nankeen night heron. The adult is easily identified by its black cap and its reddish-brown back, tail, and wings. Feeding at night and roosting by day, this large nocturnal bird is often in dense vegetation in large groups ${ }^{(24)}$.

Figure 1 shows the purple heron and rufus night heron based on the description of the informants. The description given by the informants during the conversation was the basis for the illustration of these two migrating birds.

These migratory birds were opportunistic feeders. An opportunistic feeder is a species adapted in a certain area to obtain food for existence ${ }^{(25)}$. There were a lot of fishponds surrounding the sanctuary as well as rice fields. These herons feed on fish, amphibians, insects, and their larvae, mollusks, and crustaceans such as crayfish, crabs, and shrimps as well as the eggs and chicks of other birds, and will even take mice and newly hatched sea turtles or even refuse at rubbish dumps during daylight hours. But during breeding seasons, they are responsible for collecting enough food for its chick and can stand motionless in water to rapidly strike prey with its beak. 
Table 1. Responses of the Informants on Migratory Birds

\begin{tabular}{|c|c|}
\hline Questions & Responses \\
\hline \multirow{13}{*}{$\begin{array}{l}\text { What are the different migratory } \\
\text { birds in Sampunong Bolo Wildlife } \\
\text { Sanctuary? }\end{array}$} & "The local name of this bird is "Duag". This is was the unique feature of the sanctuary ten years ago." \\
\hline & "This haven was famous long ago because of the migratory herons." \\
\hline & $\begin{array}{l}\text { "We recorded Rufus night and purple herons as migrating birds in the sanctuary. They wandered } \\
\text { due to many fishponds located within the surrounding area of the refuge place." }\end{array}$ \\
\hline & $\begin{array}{l}\text { "They find a safe place to sleep and enter it secretively so that predators don't see. They used the } \\
\text { sanctuary as a roosting place. They nest in large colonies in every tall tree in the spot." }\end{array}$ \\
\hline & $\begin{array}{l}\text { "There were two species of herons found migrating and feeding on milkfish and tilapia or even } \\
\text { shrimps and crabs from different fishponds in the surrounding area. We saw heads and bones of } \\
\text { these fishes under the trees when we roamed around the vicinity. This is one of the reasons why } \\
\text { fishpond owners and caretakers hated these species of herons." }\end{array}$ \\
\hline & $\begin{array}{l}\text { "As well as the area is hillside and the water reservoir are overflowing. Thus, these birds were resting } \\
\text { for almost } 6 \text { months from October to March every year. The rich resources are one of the reasons } \\
\text { why these birds migrated in the sanctuary." }\end{array}$ \\
\hline & "We often saw an elongated purple heron." \\
\hline & $\begin{array}{l}\text { "Also, rufus night heron resting in the big trees and feeding in some of the fishponds near the sanc- } \\
\text { tuary." }\end{array}$ \\
\hline & $\begin{array}{l}\text { "I often saw a nocturnal Rufus night-heron. They are stout, medium-sized with a short neck. Also, } \\
\text { they have relatively short, thick beak and easily identified by its black cap and its reddish-brown } \\
\text { back, tail, and wings." }\end{array}$ \\
\hline & $\begin{array}{l}\text { "I often saw a nocturnal Rufus night-heron. They are stout, medium-sized with a short neck. Also, } \\
\text { they have relatively short, thick beak and easily identified by its black cap and its reddish-brown } \\
\text { back, tail, and wings." }\end{array}$ \\
\hline & $\begin{array}{l}\text { "I often saw a nocturnal Rufus night-heron. They are stout, medium-sized with a short neck. Also, } \\
\text { they have relatively short, thick beak and easily identified by its black cap and its reddish-brown } \\
\text { back, tail, and wings." }\end{array}$ \\
\hline & "You can see them often flying. They look so beautiful." \\
\hline & $\begin{array}{l}\text { "The underparts of this herons are white, its face and neck are whitish with a reddish-brown wash, } \\
\text { and there may be a white lines around its eye and the undersides of the wings are white, with } \\
\text { cinnamon-brown flight feathers." }\end{array}$ \\
\hline
\end{tabular}

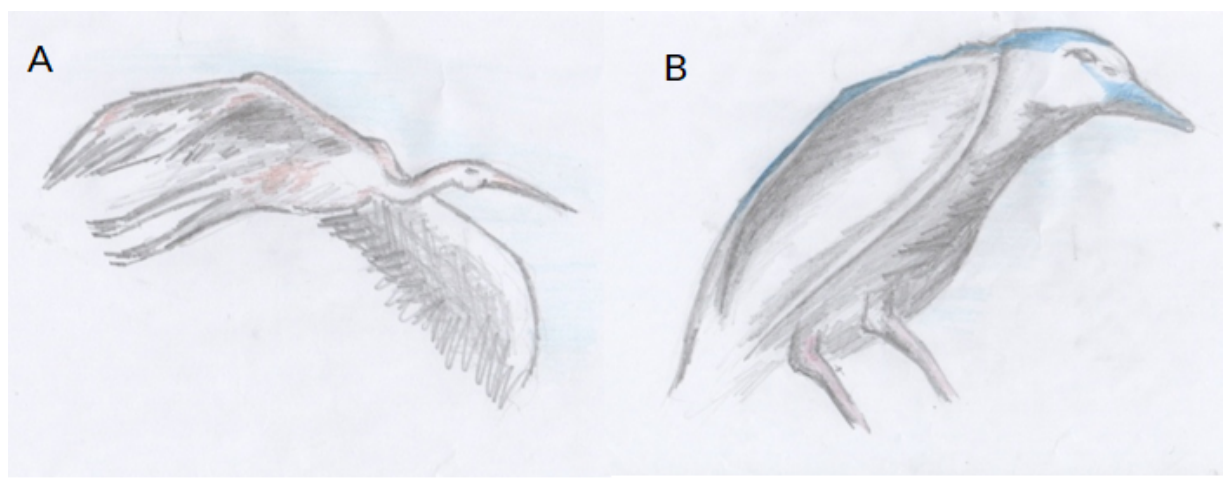

Fig 1. Illustration of two common herons found migrating in the area according to the informants (A. Purple Heron, B. Rufus-night Heron) 


\subsection{Local birds in the sanctuary}

Summarizes the responses of the informants on the local birds inhabiting the area. The abundance of big trees suitable for nesting, many other local birds were interested to reside in the sanctuary. The richness of food for survival also encourages these birds to migrate to the area.

Table 2. Local birds found in the Sanctuary

\begin{tabular}{ll}
\hline Question & Responses \\
\hline What local & "Local birds are everywhere in the area; you could even hear them making sounds." \\
birds are & "These birds are local in the place. They flocked in the trees during day time. They were flying to search for food." \\
found in & "When I was a kid together with my friends, we went to the mountain to catch Maya and sell them to our classmates." \\
the & "We can see them flocking in the trees." \\
sanctuary? & "I saw Tulamis flying in the sky and often hear a call of Murugmon during might time."
\end{tabular}

Figure 2 is the illustration of the two local birds found in the sanctuary based on the description of the informants. These are the common local birds living in the sanctuary.

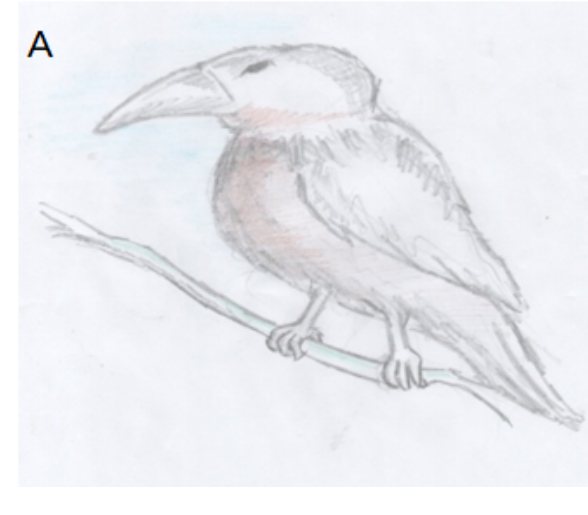

B

Fig 2. Illustration of Maya andOwl according to the informant (A. Maya, B. Owl)

There were also local birds such as Murogmo, tulamis, maya and tree sparrow. Murogmun or Philippines Grass Owl is a medium-sized, ground-dwelling nocturnal bird with a facial disc typical of the Tyto owls ${ }^{(26)}$. Tulamis is a local name for Yellow-vented Bulbul with a scientific named Pycnonotus goiavier nesting in the tropical regions. This is a species of bird in the Pycnonotidae family, it has a slight black crest and masks on an otherwise white head. Brown upper parts, pale underparts, yellow vent ${ }^{(27)}$. Black-headed Munia is also known as Tri-Colored and Black-Headed Nuns or Mannikins (Lonchura Malacca and L. atricapilla) ${ }^{(28)}$. Maya is endemic in the Philippines are also found in the sanctuary because the area is moist and the sanctuary is near a rice fields. They are also present in some countries in Europe and Asia with the official name is Eurasian Tree Sparrow or Passer montanus. Formerly the national bird of the Philippines is also known in the country as Chestnut Munia (Lonchura atricapilla or Loncura atricapilla jagori). These birds live in open habitat and nest, some of these birds are usually rest in lush and big trees.

\subsection{Local animals in the sanctuary}

Summarizes the responses of the informants of other animals commonly found in the sanctuary.

There were also animals in the sanctuary which includes, the green tree python generally with lime green in color but commonly born orange or yellow. As they age, darken and some remain yellow their entire lives. The particular way of this snake is resting on a tree branch. It will often coil itself and its head in the middle at the hilt. Another animal in the area is the mammalian fauna of the Philippines under order Chiroptera, the bats. This is considered to be one of the most species-rich in the world. This active nocturnal bat species Golden-crowned Flying Fox or Golden-capped Fruit Bat is endangered. They are roosting on protected areas of the forest to cluster in large colonies. Often interact socially, and care for their pups, they are now threatened due to bat hunters and forest users which causes stress to the Flying Fox ${ }^{(29)}$. They dwell in the sanctuary because they are protected, food is also available. And the abundance of overflowing water. 
Table 3. Other Animals commonly found in the Sanctuary.

\begin{tabular}{|c|c|}
\hline Question & Responses \\
\hline \multirow{9}{*}{$\begin{array}{l}\text { Aside from the birds, what other } \\
\text { animals are found in the sanctuary? }\end{array}$} & "We saw a yellow snake, magkal, and dahon-dahon". \\
\hline & $\begin{array}{l}\text { "This yellow snake can be applied to several different snake species such as yellow rat snake from } \\
\text { the colubrinae family or the ball python from the pythonidae family." }\end{array}$ \\
\hline & $\begin{array}{l}\text { "One residence caught a reticulated python and surrender by a local will always be returned in } \\
\text { the sanctuary to increase their population." }\end{array}$ \\
\hline & "I often saw a reticulated python in the area. But I haven't seen them now." \\
\hline & "Bats are also dwelling in the areas. Big trees in the sanctuary serve as their resting place." \\
\hline & $\begin{array}{l}\text { "This vampire eating fruit is also called flying foxes. These flying little creatures are nestling at } \\
\text { big trees in the sanctuary." }\end{array}$ \\
\hline & "Fruit bats were everywhere; they have big eyes to help see at night." \\
\hline & "They are the ones responsible for the two fruit trees growing on the property." \\
\hline & "They slept on the trees during day time and sought food at night time." \\
\hline
\end{tabular}

The bats that dwell in the area are the ones responsible for seed dispersal and is a common movement of seeds away from the parent plant so that there is less competition. This process often occurs in animals that are feeding on fruits. The most common methods are wind, water, animals, explosion, and fire ${ }^{(30)}$. There were Marang and Star Apple trees in the area. Thus, an additional 13 trees were identified in the area. Timberland revealed that is composed of new and old trees that will provide adequate forest structure and biodiversity. The forest composition has almost 18 species of plants. Also, the Municipality of Sara together with other stakeholders organized a tree planting activity at the area to assist the rehabilitation of the complex interaction among various components, preservation of its natural balance and care for it to ensure its wellbeing. Our forests maintain our climates through photosynthesis. They protect our planet from climate change by removing the greenhouse gas carbon dioxide and generating oxygen. They also help in purifying the atmosphere and controlling rising temperatures.

\subsection{Plants in the Sampunong Bolo}

Based on the conversation with the informants, there were various species of trees found in the area. Seeing Sampunong Bolo from the distance, you can see lush forests with different organisms residing in the area. There were around 13 big and tall plants everywhere. These are Ficus pseudopalma, Pterocymbium tinctorium, Nauclea orientalis, Caesulpinia sappan L., Pterocarpus indicus, Gmelina arborea, Artocarpus odoratissimus, Swietenia macrophylla, Gliricidia sepium, Chrysophyllum cainito, Ficus bejamina, Psidium guajava and Livistona rotundifolia. The plants are healthy and it's really convincing for wandering animals to migrate and roost in the sanctuary. Also, small trees, shrubs, flowering plants, different fungi, and algae as well as grasses and other forms of plants inhabit in the sanctuary.

The trees in the area were slash and burn commonly called by the locals as "Kaingin" is burning of trees for charcoal and cause destruction to the areas of deforestation. The trees are vanishing due to the community depending on them for business and for personal consumption. This becomes destructive to the environment resulting in soil erosion. The LGU started to plant trees that are not endemic in the areas, farther damage may because to the sanctuary.

Destroying our forest reserve through "Kaingin" can disturb water sources, as well as vegetation that regrows, can take around 3 to 4 years and forest trees between 15 to 18 years ${ }^{(31)}$. Without these plants, greenhouse gases will rise; thus, the temperature will also increase. Also, the destruction of our forest will affect the food chain ${ }^{(32)}$.

Thus, further study on the vegetation structure and assessed current plant biodiversity are needed. This is to determine the actual species and families as well as native plants, introduced and endemic.

\subsection{Other unique feature of the sanctuary}

Running water is also found in the area. You can hear the sound of water under the rocks. The abundance of water supports the entire ecosystem with lush green trees are everywhere; thus, different species of colorful insects and the unique sound of gecko were also rich in the sanctuary. There were flowering plants, different fungi, and algae as well as bush and grasses. The sources of running water and good sunlight are the many reasons these trees are found in the sanctuary. Aside from that, there were also various plant species in the area. This needs proper attention to help identify these organisms. There were flowering plants, different fungi, and algae as well as bush and grasses. 


\subsection{Status of migratory birds}

Table 4 show's the responses of the informants about what happens to the two migratory birds. Nowadays, no herons were resting in the trees or flying around the vicinity of the sanctuary or even feeding of fishes in neighboring fishponds.

Table 4. Responses of the informants on the common reasons for the vanishing of herons in the sanctuary.

\begin{tabular}{|c|c|}
\hline Questions & Responses \\
\hline \multirow{4}{*}{$\begin{array}{l}\text { What happened to the } \\
\text { migratory birds? }\end{array}$} & $\begin{array}{l}\text { "The purple heron vanished ten years ago because of human activities, like fires, hunting, and the area were } \\
\text { used for the housing sites for the community. Today, seldom you can see migratory birds in the vicinity." }\end{array}$ \\
\hline & $\begin{array}{l}\text { "We often heard gun shot in the area, then these birds start to fly in hordes in the sky. They are almost } \\
\text { covering the entire sanctuary, herons of various colors. They were disturbed, they hate loud sounds. After } \\
\text { these various incidents, little by little the herons begin to vanish. Nowadays, seldom you can see these } \\
\text { herons roosting in the big, tall and green trees in the sanctuary." }\end{array}$ \\
\hline & $\begin{array}{l}\text { "Human intervention such as using the area for trekking as a hobby, hunting, and land conversion are the } \\
\text { reasons that these animals disappeared in the sanctuary." }\end{array}$ \\
\hline & $\begin{array}{l}\text { "The locals hunted for herons as "puluta" or appetizers during drink sessions with friends and relatives. } \\
\text { They love to eat the meat of these migrating birds; it is similar to chicken." }\end{array}$ \\
\hline
\end{tabular}

Some people eat several species of herons elsewhere. They would like to roast, boil or stew for food. Also, these heron's fat held special medicinal value and heron wings to make brushes. People in the rural areas in the Philippines, love to drink after whole day work. Upon knowing that the flesh of these migrating birds is just like chicken, they started to hunt and kill the birds for an appetizer or "Pulutan." Also, because many of the fishpond owners got angry with the herons they started to disturb Sampunong Bolo. They make loud sounds such as firing, to distract them from roosting to prevent feeding on their fish products.

Today, seldom you can see herons roosting in the trees. They vanished more than ten years ago. The owners of fishponds were so angry since the purple herons feed on fishes and bats; thus, they used guns to disturb the birds. The herons caused a disturbance in the sanctuary as well as neighboring places that alarmed locals. The locals started to kill herons for appetizers or food.

For the past 20 years of enactment of the law for the conservation of biodiversity, implementation and management was always a common problem; a need for a strong political will as arised. As well as participation among various stakeholders is recommended ${ }^{(33)}$. There were ordinances related to the environment but not focused on local biodiversity. Thus, policies and ordinances must be created with the priorities of the local communities as well. The Sangguniang Bayan member in-charge of the environment must start to draft policies and ordinances to regulate the protection and preservation of the last frontier in northern Iloilo.

\section{Conclusion}

The abundance of "Bolo" or Bambusa levis Blanco (synonyms to Gigantochloa levis) named the sanctuary as Sampunong Bolo but need legal documents to prove it's naming. Thus, an ordinance must be formulated by the LGU. But during the natural calamities like the recent Typhoon Hyain, the sanctuary was devastated. The LGU must start to make a move to protect and preserve the sanctuary.

The two migrating herons are one of the exceptional features of the 52 -hectare timberland but because it feeds from local fish products, the fishpond owners started to disturb the sanctuary. There was also a hunting activity recorded and killed herons for appetizers. There were also other species of birds nesting in the area. The different local flora and fauna found in the sanctuary showed that the area is rich with various resources. The flying fox also added to the abundance of fruit-bearing trees. There were at least two fruit and 13 big and tall as well as other forms of plants found in the area but the burning of trees due to human activities destroyed the diversity. There were different species of colorful insects, the unique sound of gecko and quite crawling snakes were also rich in the sanctuary. There were flowering plants, different fungi, and algae as well as bush and grasses. The running water inside the sanctuary also added for the fertility of the area.

Various activities of the locals also affect the status of the sanctuary. There were no ordinances about protecting the areas. No projects and programs were also organized to rehabilitate the sanctuary. Thus, good governance is strictly encouraged to save and protect the sanctuary. Other animals and plants mentioned in the results are still existing but the LGU with the help of CENRO, DENR and State Colleges and Universities (SUCs) in the region must work together to conduct a proper survey of living things in the area. This must sustain properly. The sanctuary has a lot of potential to help the dying resources in the 
north.

\section{Sources of Funding}

This research received no specific grant from any funding agency in the public, commercial, non- -profit sectors.

\section{Conflict of Interest}

No conflict of interest has been declared by the author.

\section{Author info}

FPT is a former Master Teacher I at Ajuy National High School, Ajuy, Iloilo, Philippines teaching Science, Health, Arts, Values Education, Research and Technology and Livelihood Program from $2002-2015$. He is connected to Northern Iloilo Polytechnic State College as former Director of Research and Development Services teaching science-related courses. Currently, he is an International Research Fellow under the Japan Society for the Promotion of Science at the Hokkaido University of Education.

\section{References}

1) Biodiversity-Hub for Life: Diversity of the Philippines.. 2019. Available from: https://fpe.ph/biodiversity.html/view/hub-of-life-species-diversity-in-thephilippines.

2) Lee M. List of Natural Resources in the Philippines. USA Today. 2018.

3) Baille J, Hilton-Taylor C, Stuart SN. 2004 IUCN Red List of threatened species: a global species assessment. UK. IUCN Publication Services Unit. 2004.

4) Pettersen K. Local Autonomy: A Key to Protection of the Ecosystem. The Philippines Apo Island. 2018. Available from: https://www.asia-pacificresearch. com/local-autonomy-a-key-to-protection-of-the-ecosystem-the-philippines-apo-island/5628028.

5) Bontia E, Laguda M, Suerte NO, Clarito Q. Economic Valuation of Sicogon Island's Coral Reef Resources. Proceeding of the 9th International Conference and Scientific Meeting - Philippines Network of Educators on Environment. 2015;p. 42-42.

6) Pedregosa M, Paguntalan L, Jakosalem PGL, Lilio E. An Assessment of the Native Flora and Fauna of Sicogon Island. Panay, Philippines. 2006. Available from: https://www.researchgate.net/publication/299939212_An_assessment_of_the_native_flora_and_fauna_of_Sicogon_Island_ Panay_Philippines_a_consolidated_report.

7) Kulkarni A. Biodiversity and Sustainable Development: A Critical Analysis. International Journal of Scientific and Engineering. 2012;3(4):1-9.

8) Bekessy SA, White M, Gordon A, Moilanen A, Mccarthy MA, Wintle BA. Transparent planning for biodiversity and development in the urban fringe. Landscape and Urban Planning. 2012;108(2-4):140-149. doi:10.1016/j.landurbplan.2012.09.001.

9) Choudhary V. Definition of Wildlife Sanctuary According to Wild Protection Act 1972. 2019. Available from: http://natureconservation.in/definitionof-wildlife-sanctuary-according-to-wildlife-protection-act-1972/.

10) Econnortherwest. The Economic Importance of Alaska’s Wildlife in 2011 (Summary Report) to the Alaska Department of Fish and Game, Division of Wildlife Conservation. Portland, Oregon. 2014.

11) Wildlife Act - Focused Conservation. 2019. Available from: https://wildlifeact.com/about-wildlife-act/wildlife-tracking-and-monitoring/.

12) Callison B. Why We Need Animal Sanctuaries. 2014. Available from: https://www.livescience.com/48666-why-animal-sanctuaries-are-needed.html.

13) Rees SE, Foster NL, Langmead O, Pittman S, Johnson DE. Defining the qualitative elements of Aichi Biodiversity Target 11 with regard to the marine and coastal environment in order to strengthen global efforts for marine biodiversity conservation outlined in the United Nations Sustainable Development Goal 14. Marine Policy. 2018;93:241-250. doi:10.1016/j.marpol.2017.05.016.

14) Triantis KA, Matthews T. Biodiversity theory backed by island bird data. Nature. 2020;579. Available from: https://www.nature.com/articles/d41586020-00426-5.

15) Millennium Ecosystem Assessment. In: Ecosystems and Human Well-being: Biodiversity Synthesis. World Resources Institute. 2005.

16) Meyer KM, Sciaini M, Waveren CSV. Applications of biodiversity theories in conservation. PeerJ Preprints. 2018. doi:10.7287/peerj.preprints.27054v1.

17) Sauro J. 2015. Available from: https://measuringu.com/qual-methods/.DateAccessed.

18) Tongco JVV, Rodriguez EB, Abasolo WP, Mun SP, Razal RA. Mineral, Nutritional, and Phytochemical Profile, Total Phenolic Content, and Radical Scavenging Activity of Philippine Bamboo "Bolo"Gigantochloa levis(Blanco) Merr. Leaves. Natural Product Sciences. 2016;22:60-60. doi:10.20307/nps.2016.22.1.60.

19) Southeast Asian Fisheries Development Center. Aquaculture Department. 1994;2(3):89-89.

20) Daly S. 2017. Available from: https://focusingonwildlife.com/news/purple-herons-germany/.DateAccessed.

21) Leedwon M, Netleja J. Post-breeding migratory of Night Heron Nycticorax nycticorax tracked by GPS/GSM transmit. Journal of Ornithology. 2014;156(1.1):313-316.

22) Heron Conservation. 2019. Available from: http://www.heronconservation.org/herons-of-the-world/list-of-herons/purple-heron.

23) Hunt L. How to feed the great blue heron? Wild Sky. 2017. Available from: https://animals.mom.me/how-to-feed-the-great-blue-heron-12353022.html.

24) Hancock J, Kushlan J. The Herons Handbook. London; United Kingdom. A\&C Black Publishers. 2010.

25) Opportunistic Feeder. National Oceanic and Atmosphere Administration. Coral Reef Information System. 2014.

26) Noah P. Philippine Grass Owl (Tyto longimembis). 2019. Available from: https://www.projectnoah.org/spottings/16895033.

27) Fishpool L, Tobias J, Juana ED. Yellow-vented Bulbul (Pycnonotus goiavier). In: del Hoyo, J, Elliott, A, Sargatal, J, et al., editors. Handbook of the Birds of the World Alive. Lynx Edicions. 2019.

28) Indiviglio F. 2011. Available from: http://blogs.thatpetplace.com/thatbirdblog/2011/10/26/natural-history-and-captive-care-of-tri-colored-and-blackheaded-munias/\#.Xc48E25uKmc.

29) Filipinos for Flying Foxes: Community-Based Roost Sanctuaries for The World's Largest Bat (Acerodon Jubatus). 2019. Available from: https://www. 
saveourspecies.org/projects/bats/filipinos-flying-foxes-community-based-roost-sanctuaries-worlds-largest-bat-acerodon.

30) Seed Dispersal. Science Learning Hub. 2019.

31) Novellino D. Palawan: Should Indigenous People’s Farming Practices (Kaingin) be Blamed for Deforestation. 2015. Available from: https://www.iucn. org/content/palawan-should-indigenous-peoples'-farming-practices-kaingin-be-blamed-deforestation.

32) Michelle M. How does climate change affect biodiversity?. 2018. Available from: https://sciencing.com/climate-change-affect-biodiversity-23158.html.

33) Dizon N. DENR reports admit the Philippines is way behind biodiversity. 2012. Available from: https://newsinfo.inquirer.net/283192/denr-reportadmits-philippines-is-way-behind-biodiversity-protection. 